\title{
De chacretes, ronaldetes e outros -etes: uma análise morfológica e semântica das construções $X$-ete no português do Brasil
}

\author{
Bruna Fernanda Cândido ${ }^{a}$ \\ Carlos Alexandre Gonçalves ${ }^{b}$ \\ Maria Lucia Leitão de Almeida ${ }^{c}$
}

\begin{abstract}
Resumo
Atualmente, há uma tendência em curso na variante brasileira da lingua portuguesa: a cada dia, vêm surgindo novas palavras com o afixo-ete, iniciado com a vogal aberta, ['EtfI], como, por exemplo, 'empreguete', 'patroete', 'periguete'. Tal tendência vem atraindo a atenção de estudiosos por conta de sua crescente produtividade (GONÇALVES, 2005; ALVES, 2010; GONÇALVES, 2012). O referido formativo constitui tema do presente artigo e será aqui analisado em seus aspectos formais e semânticos. O objetivo do trabalho é analisar as formações X-ete do português brasileiro (doravante PB) à luz da Morfologia Construcional de Booij $(2005,2010)$ e de questões da Linguística Cognitiva, como os MCIs (Modelos Cognitivos Idealizados), frames e espaços mentais, para verificar (a) que aspectos desses modelos se aplicam à análise semântica do referido sufixo e (b) se existem dois afixos ['EtfI] diferentes - o designador de fãs ('ronaldete', 'neymarzete', 'luanzete') e o de dançarina/assistente de palco ('chacrete', 'angeliquete', 'panicat').
\end{abstract}

Palavras-chave: Morfologia; Linguística Cognitiva; Analogia.

\footnotetext{
a Mestre em Língua Portuguesa pela UFRJ, brufcandido@hotmail.com

b Professor da Faculdade de Letras da UFRJ, carlexandre@bol.com.br

c Professora da Faculdade de Letras da UFRJ, marialucialeitaodealmeida@gmail.com
} 


\section{Palavras iniciais}

Atualmente, há uma tendência em curso na variante brasileira da língua portuguesa: a cada dia, vêm surgindo novas palavras com o afixo -ete, iniciado com a vogal aberta, ['Et JI], como, por exemplo, 'empreguete', 'patroete', 'periguete'. Tal tendência vem atraindo a atenção de estudiosos por conta de sua crescente produtividade (GONÇALVES, 2005; ALVES, 2010; GONÇALVES, 2012). O referido formativo constitui tema do presente artigo e será aqui analisado em seus aspectos formais e semânticos. O objetivo do trabalho é analisar as formações X-ete do português brasileiro (doravante $\mathrm{PB}$ ) à luz da Morfologia Construcional de Booij $(2005,2010)$ e de questões da Linguística Cognitiva, como os MCIs (Modelos Cognitivos Idealizados), frames e espaços mentais, para verificar (a) que aspectos desses modelos se aplicam à análise semântica do referido sufixo e (b) se existem dois afixos ['EtfI] diferentes - o designador de fãs ('ronaldete', 'neymarzete', 'luanzete') e o de dançarina/assistente de palco ('chacrete', 'angeliquete', 'panicat').

O trabalho é estruturado da seguinte maneira: na seção 2, é apresentado o tratamento dado ao formativo nas gramáticas tradicionais, nos dicionários, nos manuais de morfologia e em artigos de divulgação científica. A seção seguinte é dedicada ao modelo teórico que nos serve de base para a análise aqui expendida: a Morfologia Construcional (doravante MC). Na sequência, é proposta uma análise das formações X-ete, discutindo-se o limite entre essas formas e aquelas com a primeira vogal fechada ('balancete', 'bracelete', 'bilhete'). Por último, apresentamos as principais conclusões do trabalho, procurando dar conta das diversas particularidades do sufixo.

\section{Referências ao formativo - ete}

Nesta seção, apresentamos as referências feitas ao formativo aqui analisado em gramáticas tradicionais, manuais de morfologia, dicionários e artigos de divulgação científica. Como o afixo provém do francês, começamos a recensão bibliográfica com as descrições nessa língua. Consta no dicionário eletrônico de língua francesa, "Le Petit Robert", a seguinte definição para o sufixo -ette (tratado como forma 
feminina do sufixo -et): "Suffixe diminutif, d'un lat. pop. -ittum, -ittam, entrant dans la composition de noms propres (Huguet (vx), Juliette, Pierrette), de noms tirés d'un autre nom (livret, fleurette) ou d'un verbe (frisette, sonnette), d'adjectifs (pauvret, simplet)", que, em uma tradução livre, indica ser um sufixo diminutivo com origem no latim popular, que entra na constituição morfológica de adjetivos, nomes próprios ou nomes comuns formados de outros nomes comuns ou verbos.

De acordo com Alves (2010), o sufixo -ette tem origem latina e forma que exprimem pequenez (com valor ora pejorativo, ora laudatório) ou são de natureza hipocorística. Desse modo, em francês, -ette, ao se unir a substantivos, pode (a) designar algo pequeno ('cuisinette', "pequena cozinha"); (b) expressar pejoratividade ('religionnette', "religião sem profundidade"); (c) manifestar afetividade ('demoiselette', "senhorita mimosa"); (d) formar hipocorísticos ('Claudette'). Quando a base da formação $\mathrm{X}$-ette é um adjetivo, o produto pode ter valor eufemístico ('pauvrette' - "um pouco pobre") ou valor enfático ('jeunette' - "muito jovem"). Por fim, ao se unir a bases verbais, -ette pode designar lugar (cacher - "esconder" / 'cachette' - "onde se esconde") ou instrumento (allumer - "acender" / 'allumette' "que acende").

Loures (2000) faz uma análise contrastiva dos recursos morfológicos quanto a seus valores expressivos em francês e em português, afirmando que ambas as línguas apresentam inúmeros processos derivacionais com função expressiva, por indicar a atitude subjetiva do falante (seus julgamentos de valor ou suas emoções) em relação ao enunciado. O sufixo -et(te $)^{1}$ é apontado pela autora como o formador de diminutivo mais produtivo em francês, destacando que o conceito de "pequeno" pode não estar relacionado à dimensão física, a exemplo das expressões afetivas ('ma bichette'> "minha pequerruchinha") e das construções deadjetivas, cujo significado é, geralmente, "um pouco X" ('doucette' > "um pouco doce/ adocicado").

${ }^{1}$ A autora não discrimina as duas produções de-ete, com vogal inicial aberta ['Et $\left.\int \mathrm{I}\right]$ ou com vogal inicial fechada ['e.tfI]. Começa falando de ambos, mas como o artigo tem foco nos neologismos, sobressaem exemplos com ['Et $\mathrm{I} \mathrm{I}]$.
Passemos, a seguir, às referências sobre o sufixo em português.

No dicionário eletrônico de língua portuguesa Houaiss (2009), no link “Dicionário da Língua Portuguesa”, o sufixo -ete é apresentado com vogal inicial fechada e definido como "sufixo em dim., dim. afetivos, dim. designativos de outra coisa que a normal: diabrete, ramalhete". Já no link "Dicionário de 
elementos mórficos", o -ete, com vogal inicial aberta, é definido, curiosamente, não como sufixo, mas como terminação:

1) ocorre nas orig. da língua nos numerais sete, dezessete/ dezassete; 2) ocorre do sXVI em diante em palavras como alfitete, canivete e poucas mais (arabismo o primeiro, provençalismo ou catalanismo, o segundo); 3) ocorre a partir do sXIX quase que exclusivamente em estrangeirismos, galicismos ou anglicismos, com exceção 20 do grupo de -micete, ver; galicismos: anisete, brochete, caminhonete, carpete, casquete, cassete, cassetete, charrete, claquete, coquete, cotonete, croquete, egrete, garçonete, grisete, lanchonete, manchete, maquete, marionete, marquisete, moquete, omelete, patinete, pierrete, plaquete, raquete, soquete, tablete, toalete, vedete etc.; anglicismos: basquete, chiclete, escrete, gilete, ninfete, ofsete etc.; italianismos: confete, espaguete etc.; 4) nos usuários com relativo metalinguismo, parece presente o sentimento de exotismo nesta term. ou no suf.; isso é ostensivo, no Brasil, quando se busca associar o modernoso com certo picaresco: chacrete, jambete, tiete etc.; ou quando se busca dar atrativo comercial publicitário ao produto: quitinete, colchonete, cotonete, sofanete; ver -ete \êl" (HOUAISS, 2009)

Nas gramáticas e nos manuais de morfologia, observamos que o sufixo -ete é referenciado de maneira muito breve (quando isso acontece). Nos trabalhos de Vazquez Cuesta (1982), Rocha Lima (1979), Luft (1979) e Kehdi (1992), o sufixo, assim como as formas fonologicamente relacionadas, a exemplo de -eta ('banqueta','corneta', 'chupeta'), -eto ('livreto', 'soneto','quarteto') e -ete, com vogal fechada, [e], ('balancete', 'lembrete', 'sabonete'), sequer são citados. Said Ali (1931), apesar de mencionar -eta na seção que trata dos sufixos diminutivos, não apresenta considerações em relação ao afixo aqui analisado. Sandmann (1988) é o morfólogo que discute mais amplamente o sufixo em questão ao discorrer sobre os diminutivos. Assim como ele, Cunha (1982) e Câmara Junior (1975) mencionam a origem francesa/ italiana do formativo. Sandmann (op. cit.: 38) não discrimina entre ['Et $\mathrm{II}$ e ['e.tSI], já que lista como exemplos da terminação gráfica -ete casos com vogal aberta e fechada. Entre os exemplos citados pelos autores, incluem-se os seguintes: 'cartazete' (['e.tfI]), 'disquete' (['Et $\mathrm{Ct}]$ ), lembrete (['e. tfI]) e 'sofanete' (['Ct $\mathrm{II}]$ ).

Em Bechara (1999), -ete é apresentado na listagem dos principais sufixos diminutivos, juntamente com -eta e -eto, sendo ilustrado pelos seguintes exemplos: 'saleta', 'diabrete', 'livreto', 'saberete'. Cunha (1982) aborda o -ete com vogal 
fechada, mencionando sua origem italiana e francesa. Destaca que -ete, -eto, -ito (ou -zito) e -ote têm origem obscura e interpreta os formativos como tendo função de expressar, predominantemente, dimensão. $O$ autor se contradiz ao indicar a provável origem francesa dos formativos -ete e -ote e a origem italiana de -eto e afirmar, como dito mais acima, que a origem desses sufixos seria obscura.

Na seção intitulada "Criação de novos afixos", Gonçalves (2005: 86) menciona algumas características pertinentes ao formativo em questão, sinalizando a alta produção de novas palavras no português brasileiro contemporâneo. $\mathrm{O}$ autor utiliza os vocábulos 'malufete', 'angeliquete', 'guguete' e 'lulete', afirmando que tais formas apresentam a ideia de "alguém do sexo feminino caracterizado por algum tipo de adesão a $X^{\prime \prime}$ e que, possivelmente surgiram por analogia a 'tiete', vocábulo no qual a sequência -ete não constitui afixo e não leva a significado algum.

Alves (2010) faz uma análise do emprego do formativo no PB contemporâneo, enfocando as unidades lexicais neológicas e deixando de fora as formações que apresentam terminação análoga ao sufixo por resultarem de adaptação de unidades lexicais de origem estrangeira (galicismos, anglicismos e italianismos), a exemplo de 'baguete', 'basquete' e 'chiclete'. Na introdução, ressalta as acepções e características pertinentes ao -ete apontadas pelos dicionaristas, a saber: diminutivo afetivo ou dimensivo ('palacete', 'chumacete'), terminação de numerais ('sete', 'dezessete'), palavras surgidas no XVI ('alfinete', 'canivete') e no século XIX (galicismos: 'caminhonete', 'charrete'; anglicismos: 'chiclete'; italianismo: 'espaguete'), exotismo ('chacrete', 'jambete') e, por fim, com o que não concordamos, atrativo comercial ('quitinete', 'colchonete'). A autora não discrimina a qualidade vocálica da tônica de -ete. Afirma, ainda, que, no PB, -ete é adjungido majoritariamente a bases substantivas ('colchonete'), raramente a bases adjetivas ('maluquete' - "um pouco maluco") e, ao contrário do que ocorre no francês, não forma derivados de base verbal.

$\mathrm{Na}$ análise de Alves (2010), os substantivos formados com -ete (a) designam peças pequenas do vestuário feminino ('sunguete' - "sunga feminina"); (b) podem apresentar valor diminutivo pejorativo ('programete' - "programas curtos e de 
${ }^{2}$ A Morfologia Construcional não trata somente desses casos; seu aporte inclui estudos sobre compostos e construções sintáticas e a distinção entre flexão e derivação, além da análise morfológica e semântica de formativos, como é o nosso caso. pouca importância"); e (c) designam estilo de vida ou marca que, em determinado momento, está na moda ('dasluzetes' por "vendedoras das lojas Daslu"). Por fim, Alves destaca que quando o nome próprio é de um artista, as formações X-ete podem designar dançarinas/assistentes de palco ('guguete') ou fãs ('luanzete'). Considerando as abordagens apresentadas acerca do formativo analisado no presente trabalho, notamos que muito há que se falar acerca do sufixo, uma vez que as abordagens não dão conta da variedade de empregos que as construções X-ete apresentam, além de não explicitarem como se relacionam os vários sentidos do afixo, razão pela qual analisamos -ete à luz da Morfologia Construcional, modelo descrito na seção seguinte.

\section{A Morfologia Construcional e a Linguística Cognitiva}

A Morfologica Construcional surge no cenário dos estudos linguísticos como alternativa eficaz para análise de processos morfológicos instáveis, que não podem ser encaixados perfeitamente nos padrões canônicos da composição e da derivação ${ }^{2}$. Booij (2010: 03) faz a seguinte apresentação da teoria:

Na Gramática de Construções, a gramática das línguas naturais é vista como um inventário estruturado de construções, isto é, padrões de forma-significado, em vários níveis de abstração. Na Morfologia Construcional, nos focamos nas construções no nível da palavra, mas não só elas, como também construções frasais com propriedades de palavras.

Palavras complexas são idiomas construcionais no nível da palavra, apresentando uma parte fixa e uma parte variável - no caso das construções em -nejo(a), a parte fixa é o formativo e a variável são os nomes que se adjungem à esquerda. Esquemas construcionais, nos termos de Gonçalves e Almeida (2014: 165), "são padrões gerais de pareamento forma-conteúdo que captam características comuns entre várias instanciações específicas e podem ser usados produtivamente".

Um esquema construcional pode gerar subesquemas, que também podem se desdobrar em outros subesquemas, uma vez que são estruturas simbólicas que formalizam conceitos armazenados na memória, a partir da abstração de experiências do mundo em que generalizações são realizadas. 
Por causa dessa propriedade, Booij acrescenta a especificação semântica genérica aos esquemas.

Gonçalves e Almeida (2014: 178) discorrem sobre o aporte da Gramática das Construções, buscando uma conceituação para o termo construção que seja mais aproximada do nível da palavra. Assim, definem as construções como "interseções de níveis diferentes da língua organizadas hierarquicamente por meio de ligações por herança em uma espécie de rede ou teia". As relações de herança, postuladas inicialmente por Goldberg (1995), podem ser especificadas abaixo:

a) Herança por polissemia - refere-se à extensão de significado de uma construção para outra. É o caso do sufixo-dor, que forma agentes profissional ('zelador') e não-profissional ('fraudador'), instrumento ('gravador') e objeto ('pregador').

b) Herança por metáfora - refere-se a duas construções relacionadas por projeção interdominial. É o caso de 'camisinha', "peça que protege partes do corpo em diferentes domínios" (GONÇALVES; ALMEIDA, 2014: 176).

c) Herança por subparte - ocorre quando uma construção é parte constituinte de outra, como em 'homo', ressemantizada a partir de 'homossexual', passando essa informação em 'homofobia' e 'homoafetivo', diferente do significado no nó mais alto - igual, o mesmo.

d) Herança por instanciação - ocorre quando uma construção apresenta grau de detalhamento maior, como em 'batedeira' e 'iogurteira', que possuem esquemas construcionais específicos em relação ao esquema básico - no primeiro, a base é verbal; no segundo, a base é substantiva.

${ }^{3}$ Nesse esquema, base e produto são indexados pelo símbolo subscrito ${ }^{\prime}$ que representa a classe dos substantivos. Os subscritos ${ }_{i} e_{j}$ indicam que tanto a base, representada pela variável $x$, quanto o produto, fazem parte do léxico.

A partir da noção de esquema construcional e relação de herança, Gonçalves e Almeida (2014: 187) propõem o seguinte esquema para o formativo $-n e j o^{3}$ : \\ $[\mathrm{X}] \mathrm{y} \mathrm{Y}] \mathrm{y}$}

$\left[[\mathrm{X}]_{\mathrm{Si}_{\mathrm{i}}} n e j o\right]_{\mathrm{Sj}_{\mathrm{j}}} \leftrightarrow[$ SEMi relacionada à música sertaneja]j

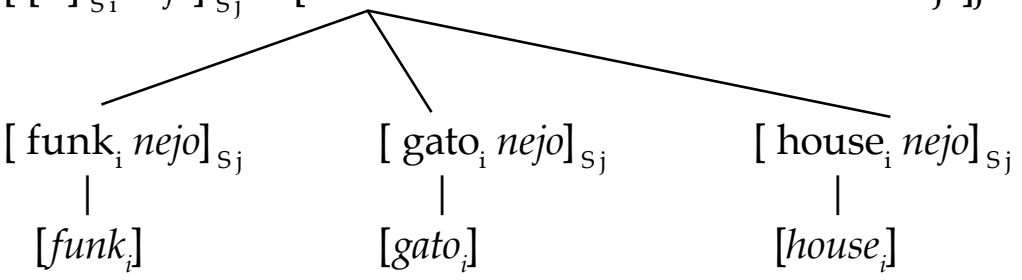


As construções são apresentadas como instanciação do esquema básico de sufixação - [ [X]y Y ]y, em que y é uma etiqueta lexical, $X$, uma forma livre e $Y$, uma forma presa à direita. A leitura feita para tal esquema é a de que SEM é interpretado como o frame evocado pela palavra-fonte. Inicialmente, o esquema feito pode aparentar que se trata de uma relação de herança por polissemia, pois é o mesmo tipo de esquema utilizado para o sufixo -dor (GONÇALVES; ALMEIDA, 2014: 179).

Entendemos que o esquema apresentado pode acolher as formas morfologicamente complexas analisadas neste trabalho, mas há necessidade de abordar questões da Linguística Cognitiva que sustentam, ainda mais, a descrição semântica do afixo. Nos termos de Almeida et al. (2010), a Linguística Cognitiva (doravante LC) é uma empreitada ${ }^{4}$ intelectual que teria nascido no ano de 1989, na Primeira Conferência Internacional de Linguística Cognitiva, com a criação da Associação Internacional da Linguística Cognitiva. Dentre os vários conceitos abordados pela Linguística Cognitiva, destacaremos, na sequência, aqueles mais relevantes ao nosso estudo: frames, MCIs, categorização, blending ou mesclagem conceptual (Teoria dos Espaços Mentais).

O termo frame se desenvolveu num programa de pesquisas, cujo líder era Charles Fillmore. O referido linguista define frame como um "sistema de conceitos relacionados de uma maneira tal que, para entender qualquer um deles, é preciso entender toda a estrutura em que se insere" (cf. ALMEIDA et al., 2010: 23). A noção de frame se aproxima da noção de domínio de Langacker (1987). Na literatura, encontramos o exemplo da cena comercial para ilustrar a noção de frame. Assim é que verbos como 'comprar', 'vender', 'adquirir', entre outros, ativam elementos que funcionam como agentes da compra (comprador e vendedor), a mercadoria, a forma de pagamento etc, que serão focalizados ou subfocalizados em função da instanciação firmada. A título de exemplificação, tomemos a frase "comprei um carro" que, por sua vez, subfocaliza o preço e o vendedor, por exemplo, enquanto a

${ }^{4}$ Por não constituir um corpo teórico claramente unificado, a LC é chamada de "empreitada" e não de teoria (ALMEIDA et al., 2010: 16). frase "ganhei um carro" subfocaliza aquele que presenteia, o preço e o vendedor, pois a cena não é de compra (é posterior a ela): é "doação". A noção de frame se comunica com o conceito de MCI (Modelos Cognitivos Idealizados), de Lakoff (1987), 
haja vista que os MCIs são "representações cognitivas de base cultural que definem um horizonte de pressupostos (frames) a partir das quais as palavras são interpretadas" (ALMEIDA et al., 2010: 24). Poder-se-ia definir a palavra 'solteirão' como "homem adulto não casado". E no caso do Papa e do Tarzan? Esses dois tipos de indivíduos são homens adultos e não casados, mas não são exemplos de 'solteirão'. Assim, a palavra 'solteirão' não se ajusta a esses indivíduos, dada a sua situação civil, mas isso não invalida tal definição, pois é verdadeira para nossa cultura, que tem a expectativa de um homem adulto estar devidamente casado e, quando isso não ocorre, o indivíduo é chamado de 'solteirão'. Em contrapartida, é inadequado chamar o Papa e o Tarzan de solteirões e isso se dá pelo fato de que a expectativa cultural do casamento não se aplica a um celibatário e a um homem isolado na selva, criado por macacos, sem contato com seres humanos (ALMEIDA et al., 2010: 23). Dessa forma, o frame que monta o cenário para o uso adequado de 'solteirão' corresponde a uma "versão estereotipada da realidade", representada pelo nosso MCI de casamento (ALMEIDA et al., 2010: 24). O uso da palavra "idealizado" por Lakoff leva em conta o fato de que as representações culturais são idealizadas/ generalizadas, simplificadas em relação ao mundo real, visto que nem todo casamento é heterossexual e monogâmico e nem toda pessoa casa na idade "ideal".

Cabe aqui explanar outro aspecto da LC aplicado na análise: "os efeitos prototípicos". Na Teoria dos protótipos de Rosch (1973), postula-se a existência de membros mais centrais para representar uma categoria em relação a outros. Os membros mais centrais, ou seja, os prototípicos, são os que reúnem maior quantidade de propriedades inerentes àquela categoria. Dessa forma, no processo de categorização, uma andorinha seria um membro prototípico da categoria "aves", pois andorinhas possuem todas as características pertinentes às aves, como bicos, penas, asas (com capacidade de voo). Já um pinguim, por exemplo, também é uma ave, mas, se comparado a uma andorinha, por exemplo, é mais dificilmente categorizado como ave, pois suas asas não são adaptadas ao voo.

Outro modelo teórico que faz parte da Linguística Cognitiva e que contribui para o desenvolvimento de nossa análise é a Teoria dos Espaços Mentais (FAUCONNIER, 1985). Os espaços mentais são "domínios conceptuais que contêm 
representações parciais de entidades e relações em um cenário percebido, imaginado ou lembrado" (FERRARI, 2011: 109). Nesse contexto, cabe também falar de mesclagem conceptual (ou blending) (FAUCONNIER \& TURNER, 2002). A mesclagem é uma operação mental através da qual estabelecemos uma projeção entre o Input 1 e o Input 2, o que permite uma correspondência entre elementos análogos que, por sua vez, é licenciada pelo Espaço genérico, representante da estrutura abstrata que os espaços iniciais têm em comum. O quarto espaço (mescla ou Blend) reúne elementos projetados dos inputs, estabelecendo uma estrutura emergente que não existe nos espaços iniciais (FERRARI, 2011: 121). O processo se constitui da seguinte maneira: primeiramente, é feita a projeção parcial entre elementos correspondentes dos Inputs 1 e 2; o espaço genérico reflete a estrutura e a organização abstrata em comum entre os inputs, ou seja, a estrutura compartilhada por esses domínios; em seguida, os inputs são parcialmente projetados no espaço mescla. Tais questões serão exploradas com mais vagar na seção seguinte, quando da análise dos dados.

\section{De dançarinetes e fanzetes}

Os dados aqui analisados foram coletados a partir das seguintes fontes: (a) conversas espontâneas de falantes do português brasileiro nas mais variadas situações de uso (entre os meses de março e agosto de 2014); (b) busca nos dicionários eletrônicos Aurélio (HOLANDA, 2008) e Houaiss 3.0 (2009); e (c) rastreamento eletrônico pela ferramenta de busca Google, a qual nos redireciona a diversos tipos de páginas da internet, configurando-se como ferramenta muito vantajosa pelo fato de fornecer dados de fontes variadas, como sites de jornais e revistas (linguagem mais formal) e blogs, chats (menos formal). Também utilizamos a ferramenta online Google Books para verificar a datação das primeiras ocorrências de alguns dados.

Nos termos de Ferrari (2011: 31), “a categorização é o processo através do qual agrupamos entidades semelhantes (objetos, pessoas, lugares etc.) em classes específicas". Na Teoria dos Protótipos, é postulado que existem membros mais centrais para representar uma categoria que outros. $\mathrm{O}$ protótipo (ou elemento prototípico) é, nesse caso, aquele que melhor representa a categoria, isto é, ele é aquele que reúne a 
5 Porém, podemos identificar uma substantivização do adjetivo 'longo', como na frase “Não sei se vou de longo (vestido) ou com um longuete mesmo". maior quantidade de características que o falante reconhece como marcas fundamentais de determinada classe. Com base nos conceitos de categorização e protótipos, os dados rastreados foram distribuídos em grupos de afinidade morfossemântica, ou seja, as palavras que compõem o corpus foram divididas em grupos que veiculassem sentido afim, para que fosse possível observar as características de cada agrupamento e sua produção efetiva no PB contemporâneo.

O primeiro grupo de formas $\mathrm{X}$-ete veicula a ideia de pequenez. Assim sendo, podemos dizer que -ete remete a "coisas pequenas concretas" ou "tipo menor de X". Como, nesse grupo, o formativo tem função de especificar, designar objetos, podemos afirmar que o sufixo -ete, nessa acepção, tem função denominadora, nos termos de Basilio (1987). Os dados que figuram neste grupo são os listados em (01):

$\begin{array}{lll}\text { (01) bagulhete } & \text { sofanete } & \text { belisquete } \\ \text { longuete } & \text { bofete } & \text { mobilete } \\ \text { colchonete } & \text { camisete } & \text { caminhonete } \\ \text { soquete } & \text { disquete } & \text { quitinete }\end{array}$

Percebemos que as formações desse grupo se caracterizam por apresentar bases substantivas. Até mesmo no caso das formações cujas bases são originárias de outras línguas, temos substantivos, como 'bofete' (buff - tapa, em inglês), 'quitinete' (kitchen - cozinha, em inglês), 'soquete' (sock - meia, em inglês). Pelo fato de serem oriundas de outras línguas, tais bases não possuem autonomia discursiva e, portanto, a elas não se anexam outros sufixos. O único caso de formação X-ete, neste grupo, cuja base não é um substantivo, é 'longuete' (base adjetiva, longo) ${ }^{5}$. Quanto ao produto, percebemos que não há mudança na categorização lexical das bases, uma vez que o molde [[X]s ete]s tem etiquetas lexicais idênticas.

O segundo grupo de formas X-ete pode ser apontado como o mais produtivo. Os dados que o compõem remetem ao conteúdo de práticas comportamentais e sociais da mulher não bem aceitas socialmente, que denotam desapreço. Por conta disso, o cunhamos "depreciação feminina". Os termos possuem diferentes origens; portanto, propomos três subgrupos, listados e detalhados a seguir. Verificamos, em todos os subgrupos, que 
Apesar de o segundo grupo ser chamado de "depreciação feminina", ressaltamos que as formações que compõem o subgrupo $\mathrm{C}$ podem designar tanto homens quanto mulheres. O uso desse -ete remetendo a homens é depreciativo, sendo o estado de euforia, típico dos fãs, associado ao feminino e, consequentemente, ao gay. a referência ao feminino é evidente no produto da formação, exceto em 'peguete', que, hoje em dia, pode designar tanto o homem quanto a mulher com quem alguém se relaciona de forma descompromissada. As formações que se enquadram neste grupo são expostas em (02), cada uma em seu subgrupo correspondente:

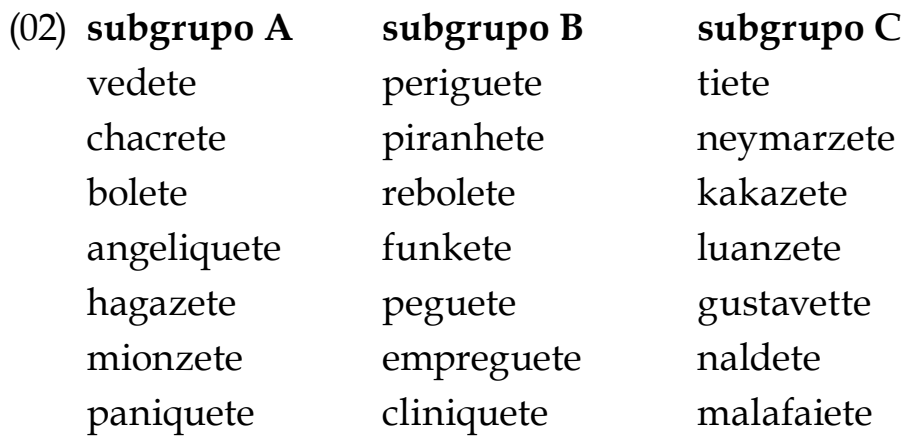

Conforme afirmado mais acima, os dados do subgrupo A têm origem diferente daqueles listados no subgrupo C. Há fortes indícios de que as formações em -ete designando bailarinas/ assistentes de palco de programas de televisão - tais como 'chacrete' (do antigo programa do Chacrinha), 'bolete' (do antigo programa do Bolinha) e 'paniquete' ou "panicat" (do atual programa Pânico na TV, da Bandeirantes) - foram criadas, como sugere Gonçalves (2012), por analogia ao termo 'vedete' (oriundo de estrangeirismo) que, por sua vez, caracteriza mulheres que "apresentavam espetáculo teatral composto de números falados, musicais, coreográficos e humorismo, exibindo a beleza do corpo com pouca roupa de forma exuberante" (www. dicionarioinformal.com.br/vedete. Acesso em 10/03/2016).

As palavras do subgrupo $C_{,}^{6}$ nas quais o formativo se anexa a um nome próprio para indicar "fã/seguidor(a) de $X^{\prime \prime}$ - tais como 'neymarzete' e 'kakazete' (fãs dos jogadores de futebol Neymar e Kaká, respectivamente), 'luanzetes', 'gusttavetes' e 'naldetes' (fãs dos cantores Luan Santana, Gusttavo Lima, Naldo Benny, respectivamente) e 'malafaietes' (seguidoras do Pastor Silas Malafaia) - surgem por analogia a 'tiete' (GONÇALVES, 2012). Esse termo era um hipocorístico atribuído às admiradoras do cantor Ney Matogrosso, que era chamado de "tio/ titio" (cf. HOUAISS, 2009). Assim sendo, um novo uso para o afixo -ete se deu por analogia (GONÇALVES, 2012). De acordo com Gonçalves (2012), teríamos os esquemas 
abaixo para ilustrar as origens do subgrupo A (03) e do subgrupo C (04):

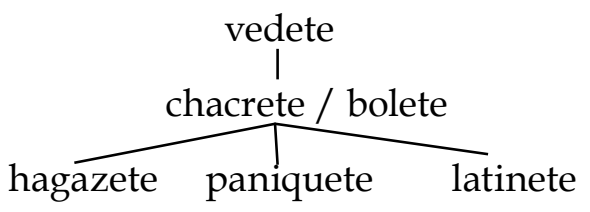

(04)

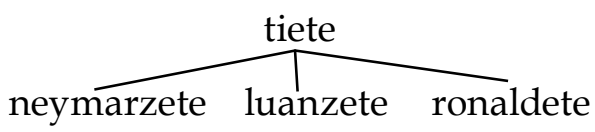

No esquema (03), desenvolvido por Gonçalves (2012) para as formações do grupo A, os termos 'chacrete' e 'bolete' estão representados no mesmo nível, pois ambas são palavras que surgiram na nossa língua na década de 50, sendo motivadas, no mesmo grau, por 'vedete', ou seja, não foi o caso de um motivar o outro. Então, os dois influenciaram a criação analógica de todos os termos designadores de assistentes de palco de programas televisivos, a exemplo da recentíssima 'thiaguete' (assistente de palco do apresentador Thiago Leifert, do programa The Voice Brasil, da Rede Globo).

Com exceção das palavras 'vedete' e 'tiete', que servem de motivação para as demais formações, os dados que pertencem aos subgrupos A e C possuem, como base, o nome do artista de quem se é assistente/dançarina (subgrupo A) ou seguidor/ fã (subgrupo C); desse modo, assim como no primeiro grupo exposto na presente análise, temos um substantivo formando outro substantivo, como no esquema [[X]s ete]s. Pelo fato de ser o grupo que apresenta maior quantidade de novas formações, este tem sido o mais discutido e analisado por estudiosos, como salientamos na seção 2 .

Alves (2010) afirma que a maior parte das formações em -ete tem como base um substantivo que denota um personagem (artista de televisão, político, atleta), um estilo de vida ou marca que, em um determinado momento, está na moda. Assim como nós, também a autora ressalta que, quando o nome próprio é um artista, as formações X-ete podem designar dançarinas/ assistentes de palco, tais como 'latinetes' (dançarinas do cantor Latino) e 'guguzetes' (assistentes de palco do programa do Gugu Liberato), ou, então, podem remeter a fãs ardorosos, como 
7 Perfil falso da presidenta Dilma Rousseff nas redes sociais twitter e facebook, de cunho crítico, político e humorístico.

8 Sigla de Lésbicas, Gays, Bissexuais, Travestis, Transexuais e transgêneros, utilizada para identificar todas as orientações sexuais minoritárias e manifestações de gênero diferentes daquele designado ao indivíduo no nascimento. 'kakazetes' (fãs e admiradoras do jogador Kaká). Nos casos em que a base é o nome de um político, como salienta Alves, temos formações com designações variadas, do tipo 'malufetes' (mulheres que faziam a propaganda do político Paulo Maluf) e 'santanetes' (mulheres belas que eram "acompanhantes" do político português Pedro Santana Lopes).

Cabe aqui enfatizar a pejoratividade que as formações $\mathrm{X}$-ete apresentam, quando o X é nome de um político, pois, ao mesmo tempo em que 'freixete' designa "seguidor e militante de Marcelo Freixo", aqueles que trabalharam na campanha de candidatura de Freixo a prefeito do município do Rio de Janeiro não gostavam de ser chamados de 'freixetes', pois o termo era usado com deboche pelos militantes dos demais candidatos, pela oposição, com o objetivo de não legitimar a militância, peça fundamental da campanha desse candidato. Além de 'freixete', encontramos outro dado que também apresenta a mesma característica, a saber 'dilmete'. A formação "dilmete" pode designar as modelos que participaram da campanha eleitoral à presidência da Republica de Dilma Roussef, mas também pode se referir às ministras do governo Dilma e, ainda, aos seguidores da "Dilma Bolada"7. A pejoratividade, neste último caso, consiste na ironia com que o termo é utilizado, visto se tratar de uma página/perfil de humor na internet e, assim, os/as 'Dilmetes' não são os fãs da "presidenta", mas da personagem "Dilma Bolada".

Uma das mais recentes formações X-ete é 'malafaiete' que, por sua vez, tem como data de sua primeira ocorrência no Google julho de 2012 e designa fãs/seguidoras de Silas Malafaia. O polêmico líder da Igreja Vitória em Cristo conquistou muitos opositores após uma entrevista na qual se posicionou quanto a diversos assuntos que figuram na sociedade atual, dentre os quais, principalmente, a homossexualidade. Por conta disso, administradores e autores de blogs e de páginas das redes sociais, sobretudo aquelas de temas LGBTT $^{8}$, começaram a tecer comentários agressivos que atacavam diretamente o pastor e sua posição (não menos agressiva e ofensiva) frente aos homossexuais. Isso gerou enormes debates e confrontos entre os blogueiros e os defensores de Malafaia que, por conta dessa ocasião, passaram a ser chamados, por sarcasmo, de 'malafaietes'. Apesar de todo o segundo grupo apresentar dados com teor de pejoratividade, o subgrupo B, sem dúvida alguma, 
pode ser destacado como aquele que possui maior quantidade de formações pejorativas que veiculam, nitidamente, desapreço, perceptível em 'periguete', 'peguete', 'piranhete'.

Otermo'empreguete' apresenta granderepresentatividade e popularização por ser o nome artístico de um trio de cantoras da novela "Cheias de Charme" (Rede Globo, 2012) e pode ser definido como (i) "mistura fina entre 'empregada' e "periguete"' (Dicionário Informal) ou ainda como (ii) mistura de empregada com 'chacrete', por conta do visual extravagante das moças (Wickicionário). Na ficção, as 'empreguetes' eram domésticas que, apesar de muito competentes, constantemente eram humilhadas por suas patroas e, sonhando com o sucesso na carreira artística, lançaram a música "Vida de empreguete", que versa sobre a dura vida das domésticas e o tratamento desrespeitoso e cruel por parte das patroas. Como resposta, Chayenne (uma patroa malvada e cantora de sucesso, personagem de Cláudia Abreu) lança a música "Vida de patroete", criando, então, em contraposição ao termo 'empreguete', novo termo "viral".

A criatividade linguística dos falantes permitiu a formação, por analogia à 'empreguete', não somente de 'patroete', mas também de diversas formações que se referem a profissionais que, por mais competentes e empenhados que sejam, são desvalorizados ou mal remunerados, como 'professorete', 'cliniquete', 'enfermeirete'. Em 'peguete', o desapreço vem da ideia de que não se trata de uma pessoa digna de se assumir o compromisso de um relacionamento sério, um alguém que só serve para 'pegar': "Informalmente, o ato de pegar pode significar agarrar uma mulher. Não há como saber quão profundo foi o ato, já que "pegar" pode significar todos os níveis que uma relação pode ter, desde uns beijinhos até transar" (dicionarioinformal.com.br. Acesso em 10/03/2016).

Assim como seu sinônimo 'piranhete', a palavra 'periguete' apresenta indubitável carga de desapreço, haja vista que pode ser definida como "Mulher fácil que paquera abertamente os homens, normalmente com o intuito de tirar alguma vantagem, como: carona, roupas, joias, pagamento de contas e ajuda financeira em geral" (dicionarioinformal. com.br/periguete/. Acesso em 10/03/2016). Conforme salienta Gonçalves (2012), a palavra 'periguete' influenciou a criação das formações 'funketes' e 'reboletes' que designam 
'periguetes' que vão com alta frequência para o baile e rebolam despudoradamente ao som do funk.

Nos subgrupos A e C, à exceção de 'vedete' e 'tiete' (palavras nas quais -ete não constitui afixo), as bases são nomes próprios. Já no subgrupo B, temos os termos 'peguete' e 'rebolete', que se caracterizam por apresentar bases verbais, e 'periguete' que, por sua vez, pode ter como base o substantivo 'perigo' ou o adjetivo 'perigosa'. Nos três subgrupos, não notamos valor pejorativo nas bases. Nos subgrupos A e C, isso seria impossível, haja vista que as bases são nomes próprios, mas no subgrupo B temos 'piranhete', que apresenta o vocábulo depreciativo 'piranha' como base, configurando-se como único exemplo. Todos os produtos veiculam comportamentos e práticas sociais atribuídos a mulheres, que são mal vistos por uma sociedade ainda caracterizada pela misoginia, ou seja, esses vocábulos representam a avaliação moral negativa, motivada pela força cultural impregnada de discriminação à mulher.

O terceiro grupo da nossa proposta de análise é o designativo de "práticas sexuais", cuja ocorrência é restrita à linguagem informal, visto que os dados em (05) são classificados como tabuísmo (cf. HOUAISS, 2009).

(05) boquete cunete linguete

As formações 'boquete' e 'linguete' têm como base substantivos que designam componentes orais que são instrumentos ativos da prática sexual: boca e língua, respectivamente. Já 'cunete' tem em sua base o receptor da ação, o alvo, a forma vulgar de ânus ('cu'). Encontramos a palavra de origem francesa "minete" como possível dado para este grupo, mas não a elencamos aqui, pois é o único dado do grupo cuja origem é estrangeira e não se refere, em português, a nenhuma parte do corpo humano. Na verdade, o vocábulo já veio "pronto" para nossa língua, mantendo o mesmo significado na língua de origem. De acordo com o dicionário Houaiss (2009), a palavra francesa 'minette' designa "gatinha", mantendo assim o significado central de diminutivo do -ette, em francês. $\mathrm{O}$ dicionário de língua francesa Le Robert (2001) também define 'minette' como "gatinha" e como onomatopeia do gato em galloroman. Além disso, indica que o termo também é utilizado com 
o mesmo sentido do português, pois o 'faire minette' designa, também, fazer sexo oral na mulher. No francês informal, o órgão sexual feminino é chamado de gata ('la chatte'), o que pode ter licenciado a associação de 'minette', por metonímia, ao órgão em si e a prática oral nesse órgão.

A produtividade desse grupo é baixa, visto que a quantidade de órgãos genitais envolvidos nas práticas sexuais é obviamente reduzida e limitada. Do ponto de vista semânticopragmático, o grupo veicula a ideia de obscenidade, pois são atos considerados tabus pela nossa sociedade. Essas práticas, a depender dos MCIs do falante e de sua perspectiva, podem ser consideradas menos sexo, parte preliminar (não completa de sexo) ou, até mesmo, nem consistir em sexo. Na nossa sociedade, é comum jovens que se consideram ainda virgens, mas que praticam o sexo oral, pois as informações contidas em seus MCIs tomam por sexo somente quando há penetração. Além disso, nessas construções há ideia de submissão do agente em relação ao beneficiário.

Come se vê, a ideia de inferioridade, pequenez (física ou moral) e pejoratividade são características que a maioria das formações X-ete apresenta. Um 'colchonete' é um tipo inferior/menos confortável/menos grosso de colchão; uma 'caminhonete' é um tipo inferior/ menos potente de 'caminhão'; a 'paniquete' e a 'periguete' são mulheres consideradas vulgares, julgadas como de conduta duvidosa; a 'chacrete' e a 'neymarzete' são mulheres que estão em plano de fundo, ou seja, a existência da 'chacrete' e da 'neymarzete' depende da existência de Chacrinha e Neymar, respectivamente.

Formas terminadas em -ete igualmente empregadas no $\mathrm{PB}$, mas de origem estrangeira ou oriundas, por metonímia, de nomes comerciais ('gillete' e 'cotonete') e construções em que as bases não são passíveis de recuperação, como as listadas em (06), não foram categorizadas em nenhum dos três grupos propostos nesta análise. Isso porque tais palavras foram incorporadas ao português, já prontas, resguardando a mesma forma e o mesmo significado nas respectivas línguas de origem.

$\begin{array}{lll}\text { (06) do francês } & \text { do inglês } & \text { do italiano } \\ \text { baguete } & \text { basquete } & \text { espaguete } \\ \text { tablete } & \text { chiclete } & \text { confete }\end{array}$


${ }^{9}$ Há uma certa polêmica se a primeira "dançarinete" foi do Programa do Bolinha ou do Chacrinha. Como foi o Abelardo Barbosa ("Chacrinha") que popularizou o termo, achamos conveniente manter a direção 'vedete' $\rightarrow$ 'chacrete'.

${ }^{10}$ Ao pesquisarmos no Google, encontramos uma imagem de uma senhora de idade avançada com trajes muito curtos e vulgares, cuja legenda era "Futuro de periguete é ser vovoguete".(http://www.panelada.net/tags/fotosmuitoloucasparafacebook-vovoguete. Acesso em 10/03/2016).
A incorporação dos vocábulos listados em (06) enriqueceu o léxico da língua não apenas pelo aumento na quantidade de itens lexicais, mas também pelo fato de as palavras de origem francesa terem motivado a criação de outras que, igualmente, serviram de gatilho para novas formações (processo que continua até hoje). A título de exemplificação, temos 'vedete' (de origem francesa), empréstimo monomorfêmico que manteve o significado de "atrizes de teatro de revista" e criou, por analogia, o termo 'chacrete ${ }^{9}$ que, por sua vez, licenciou a criação de todos os dados que formam o subgrupo das "dançarinetes" (subgrupo A).

Cabe ressaltar que os falantes do PB não aceitaram a vinda dessas palavras de maneira passiva, ou seja, a criatividade linguística possibilitou a incorporação de particularidades do -ete "brasileiro" como, por exemplo, o fato de o formativo já apresentar variantes alomórficas, a saber: -nete ('cunete'), -guete ('vovoguete') ${ }^{10}$, -zete ('luanzete'). A variante -zete tem se mostrado a mais produtiva na língua, ou seja, os falantes do $\mathrm{PB}$, ao criarem novas formações com -ete, acrescentam o -z-, consoante epentética por excelência na morfologia do português (GONÇALVES, 2005; GONÇALVES \& ALMEIDA, 2008). Podemos observar isso em formação do tipo 'luanzetes' e 'guguzetes' em detrimento de 'luanetes' e 'guguetes'. Além disso, a formação 'vovoguete' nos chama a atenção, pois designa "vovó periguete", nos indicando, então, a possível herança por subparte, em que a variante -guete é uma "parte" da palavra 'periguete' que, nessa formação, carrega o significado do vocábulo inteiro. Dessa maneira, podemos afirmar que, se há desvio na forma, há variação semântica, aqui motivada pelo fenômeno do blend lexical (fusão de bases).

Ainda a respeito da origem das palavras e de sua produtividade em português, destacamos aqui o caso da palavra 'garçonete'. Alves (2010) menciona os hipocorísticos de caráter melhorativo, citando, como exemplo, o vocábulo 'garçonnette', definido como "menina mimosa" (ALVES, 2010: 203). Nossos levantamentos indicam que essa palavra existe em língua portuguesa para designar "empregada que serve à mesa ou ao balcão, em cafés, lanchonetes etc." (HOUAISS, 2009), considerada a forma feminina de 'garçon' que, por sua vez, veio do francês, língua na qual significa 'menino', mas em 
português designa "homem que serve em bares e restaurantes". No entanto, até encontramos as formas francesas 'garçonet' (diminutivo de 'garçon' - "menino") e 'garçonnière' ("pequeno apartamento onde acontecem encontros amorosos de homens com suas amantes"), mas não localizamos, em nenhum dos nossos recursos de busca (dicionários e google), o vocábulo 'garçonnette', que seria a forma correspondente de 'garçon' no feminino. Diante desse panorama, podemos afirmar que a palavra 'garçonete', ao contrário do que se imagina, é um vocábulo vernáculo, haja vista que não existe essa formação em língua francesa. Novamente, incorporamos os empréstimos, mas atuamos sobre eles, seja no sentido de formar novas unidades, seja atribuindo novos significados e usos.

\section{Dois sufixos, uma grafia}

Apesar de muitos tratarem -ete ['e.tfI] (vogal inicial fechada) e -ete ['EtfI] (vogal inicial aberta) como realizações fonologicamente diferentes do mesmo afixo, como apontamos na seção 2, defendemos que ['e.tfI] e ['Et JI] são afixos distintos, não só pelos significados diferentes que atualizam, mas também pelas origens distintas e pela diferença na forma, uma que vez que a qualidade da tônica é diferente. Na verdade, o -ete com vogal inicial fechada ['e.tfI] é oriundo da forma masculina do sufixo diminutivo francês -et e o -ete com vogal inicial aberta ['Et $\mathrm{CI}]$ tem como origem a forma feminina do sufixo diminutivo francês -ette.

Uma evidência em favor dessa hipótese é o fato de que formações realizadas com vogal fechada, tais como 'bilhete', 'bacinete', 'banquete', 'gabinete' e 'filete', mantêm o gênero masculino e resguardam o significado das formações correspondentes em língua francesa, a saber: 'billet', 'bacinet', 'banquet', 'cabinet' e 'filet', respectivamente. Além disso, notamos que são do gênero masculino até mesmo as formações com bases vernáculas (que, obviamente, não têm correspondentes idênticos em francês), a exemplo de 'angulete', 'galhardete', 'lembrete' e 'balancete'. No caso de -ête, analisado em Aragão (2011), predomina a noção de diminutivo, como em francês. Não há, portanto, sequer uma situação de homonímia, haja vista a diferença formal; são dois afixos diferentes. 
${ }^{11}$ Teríamos uma herança por subparte, uma vez que -ete é uma parte da palavra 'tiete', monomorfêmica para a maior parte dos falantes da língua, que evoca toda a palavra-fonte. Dito de outra maneira, uma 'malafaiete', por exemplo, é interpretada como "tiete de Malafaia". A ideia de 'tiete' (fã) está presente em todos os dados, graças à parte de 'tiete' levada para a construção resultante.
A terminação -éte, como vimos, traçou novos rumos em português. Inicialmente, encontramos indícios que poderiam comprovar a homonímia entre o -ete das "dançarinetes" e o -ete das "fanzetes", tais como as origens distintas, sendo o -ete de 'chacrete' oriundo do termo estrangeiro 'vedete' por analogia e o -ete de 'Malafaiete' originado por subparte do vocábulo vernáculo 'tiete' ${ }^{11}$. Assim, teríamos um -ete provindo de estrangeirismo por formação analógica e outro -ete criado por relação de subparte de um vocábulo nativo. Prosseguindo nossa análise, com base na Teoria dos Espaços mentais, encontramos uma solução mais eficaz para esse caso e concluímos, então, que temos um caso de polissemia.

Conforme já explicitado na seção 3, as mesclagens conceptuais operam em dois espaços mentais de input para criar um terceiro espaço, a mescla. A estrutura parcial dos espaços input é projetada no espaço mescla, que tem estrutura emergente própria. Considerando que, de acordo com Hutchins, "a habilidade para combinar a estrutura conceptual com a estrutura material é a chave da estratégia cognitiva" (HUTCHINS, 2005: 1556), propomos os esquemas de mesclagem conceptual, expostos a seguir, para analisar como se dão os mecanismos cognitivos ao criar formações $\mathrm{X}$-ete com significados diferentes. Dito de outra maneira, buscamos entender como o falante não confunde formações $\mathrm{X}$-ete designando assistentes de palco com formações X-ete que remetem a fã/seguidor(a). Retomando Hutchins (2005), a chave é a analogia abstrata que subjaz a ambas as mesclas que formam os diferentes grupos.

Na representação a seguir, temos a ilustração da mesclagem conceptual para a formação 'chacrete'. Nessa mesclagem, a palavra de origem francesa 'vedete', do Input 1 , pelo princípio de projeção, projeta "dançarinas do apresentador Chacrinha" no Input 2, resultando no espaço genérico "dançarinas exuberantes" e, por fim, no espaço mescla temos a forma emergente 'chacrete'. Observe-se que há, então, do ponto de vista semântico-cognitivo, duas entidades no input 2 que se relacionam por meio de uma função; nesse caso, o apresentador de programa televisivo Chacrinha e as suas dançarinas. 
Figura 01 - Mesclagem conceptual referente à formação 'chacrete'.

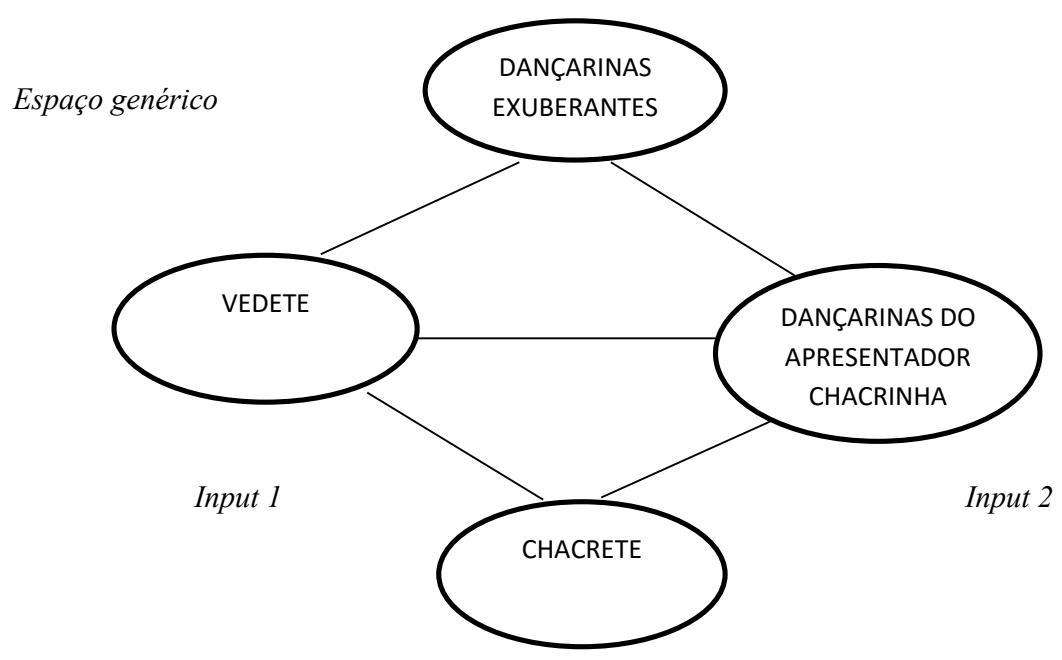

Espaço- mescla

Pela representação, é possível interpretar as demais formações X-ete designando "dançarinas/ assistentes de palco do apresentador $X^{\prime \prime}$, haja vista que o processo se dá da seguinte maneira: a palavra 'vedete' do Input 1 projeta no espaço 2 a contraparte "dançarinas do apresentador X" e, ainda no Input 2 , temos o papel-função (rule) de líder do programa. A projeção do Input 1 para o Input 2 resulta no espaço genérico "dançarinas exuberantes" e, então, temos as formas emergentes no espaço mescla ('thiaguete', 'paniquete', 'latinete' etc).

É possível fazer exatamente a mesma representação de mesclagem conceptual para as formações X-ete designando "fã/ seguidor(a) de $X^{\prime \prime}$, como podemos ver na figura 02 , na qual o vocábulo 'tiete' (a) do Input 1 projeta, no Input 2, a contraparte $\left(a^{\prime}\right)$, seguidor, e, nesse mesmo espaço, temos o papel função de ídolo (b). O Input 1 e o Input 2 projetam "fã/ seguidor(a)" no espaço genérico e, no espaço-mescla, temos a estrutura emergente $\left(a^{\prime \prime}\right.$ e $\left.b^{\prime}\right)$ : 
Figura 02 - Mesclagem conceptual referente

à formação X-ete designando fã/ seguidor.

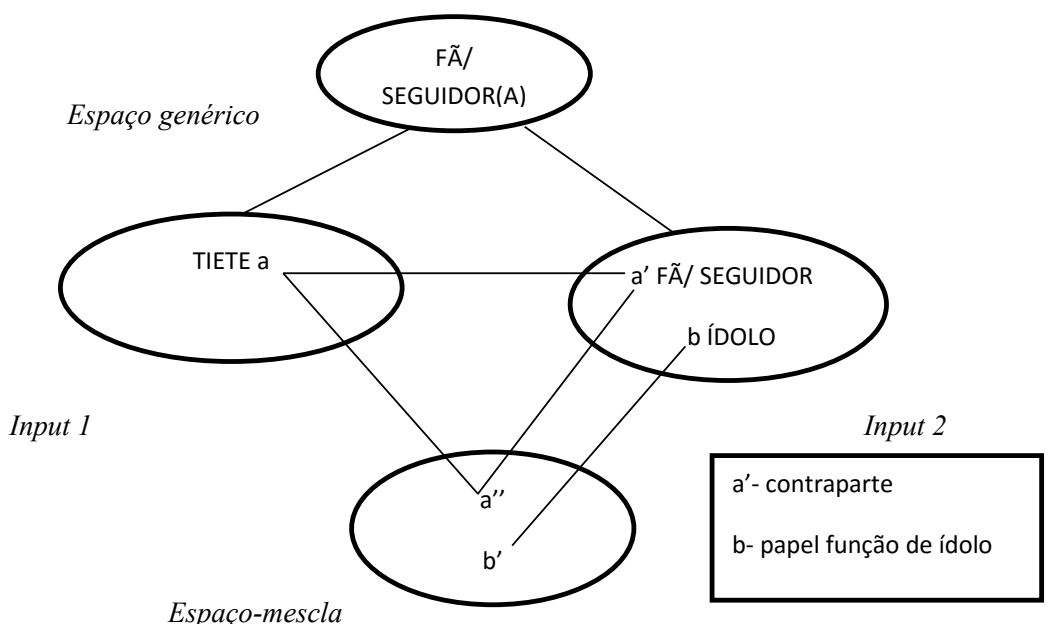

Desse modo, um mesmo mecanismo pode ser aplicado tanto para as formações X-ete designando "dançarinas de X", quanto para X-ete designando "fãs de X", ou seja, o falante faz o mesmo percurso para chegar aos dois significados diferentes e isso comprova a polissemia, pois temos então o mesmo sufixo -ete (vogal aberta) com significados diferentes, mas relacionados. Um questionamento gerado a partir dessa constatação é o seguinte: como o afixo -ete pode ser tão produtivo com essa polissemia? Como o falante não confunde o -ete para formar "dançarinas de X" com o -ete "fã de X"?

Em Hutchins (2005), encontramos a resposta com base na noção de estabilidade conceptual. Para o autor, "a estrutura conceptual deve ser representada de maneira que se possa manipular algumas partes da representação, enquanto outras partes permanecem estáveis". (HUTCHINS, 2005: 1557). Foi justamente isto que vimos nas representações acima e, por isso, dizemos que a estabilidade conceptual é o que une os dois esquemas representados na figura 01 e na figura 02 , visto que algumas partes podem ser manipuladas, mantendo a estrutura conceptual. Embora a representação cognitiva seja a mesma, os cenários culturais não são os mesmos e, por isso, o falante não confunde 'thiaguete' com 'neymarzete', pois lança mão 
dos seus MCIs e percebe que existe, em ambos os casos, uma relação na qual temos um item principal (primeiro plano), como o apresentador Thiago Leifert e o jogador de futebol Neymar, e um item coadjuvante (segundo plano), nesse caso, 'thiaguete' e 'neymarzete'. Assim, é necessário que o falante tenha na sua base de conhecimentos de mundo / cultural (enciclopédica) a informação que Thiago Leifeirt é um apresentador de programa televisivo e, por isso, pressupomos que tenha assistentes de palco/dançarinas, enquanto Neymar é um jogador de futebol e, portanto, não pode e nem precisa ter assistentes de palco/ dançarinas, mas fãs.

Por fim, um detalhe nos chamou atenção e se apresenta como mais uma evidência do uso generalizado do formativo ora em exame. No processo de levantamento de dados, encontramos uma característica do sufixo -ete no PB não descrita em nenhuma das referências analisadas para a confecção deste trabalho, mas apontada por um texto da internet escrito pelo jornalista e político Jean Willys e publicada no seu blog. Conhecido pela sua luta pelos direitos dos homossexuais, Jean salienta que o -ete é usado como recurso da fala gay para formar versões femininas de nomes próprios masculinos:

"Os exemplos se multiplicam, quem participa da cultura gay sabe disso. Sem falar dos apelidos que os gays recebem dos (e dão aos) amigos e que são versões "femininas" dos verdadeiros nomes masculinos. Versões que, em geral, terminam com o sufixo "ete". Exemplos? Silvio: Silvete; Ely: Eliete; Gildásio: Gildete; e por aí vai..."

\section{Palavras finais}

Este artigo procurou investigar as formações X-ete no PB, tendo como embasamento teórico a Morfologia Construcional de Booij e aspectos da Linguistica Cognitiva, tais como a teoria dos protótipos e categorização, a noção de frames e MCIs, a Teoria dos Espaços Mentais e mesclas (Blendings). Notamos que as descrições do formativo encontradas em gramáticas e manuais de morfologia são confusas e contraditórias, na maioria dos casos, e buscamos então realizar uma descrição mais exaustiva que possa vir a contribuir para os estudos acerca do afixo e para os estudos morfológicos e semânticos, em geral. 
Tomando como base a teoria dos protótipos, categorizamos os dados, rastreados em fontes diversas, de acordo com suas afinidades morfossemânticas e, assim, delimitamos quatro grupos, a saber: "tipo menor de X", "depreciação feminina", "práticas sexuais orais" e "empréstimos antigos". Após o processo de categorização dos dados, analisamos os grupos à luz do modelo construcionista de Booij. No caso de 'vovoguete', temos um caso de herança por subparte, uma vez que a sequência -guete remete a 'periguete', em que a oclusiva /g/ faz parte da base. Nas 'dançarinetes', a herança se dá por analogia e promove a polissemia do afixo. Assim, em relação ao questionamento do caráter polissêmico ou homonímico das formações X-ete, podemos afirmar que, entre o -ete (vogal aberta) e o -ete (vogal fechada), há uma relação de sufixos distintos, ou seja, temos formas fonológicas diferentes com significados diferentes, mas, entre as formações X-ete (vogal aberta) designando dançarinas e as formações $\mathrm{X}$-ete que designam fã/ seguidor(a), há uma relação de polissemia, isto é, temos o mesmo formativo com extensão de significado e isso foi comprovado a partir de mesclagens baseadas na Teoria dos Espaços Mentais da Linguística Cognitiva. Cumpre apresentar, em favor dessa análise, que apresentadores também têm fãs e, por isso, são naturalmente polissêmicas formações como 'lucianete' e 'faretes', que podem ser interpretadas como dançarinas ou fãs, nessa ordem, dos apresentadores Luciano Huck e Rodrigo Faro.

\section{REFERÊNCIAS}

ALVES, I. M. O sufixo -ete no Português Brasileiro Contemporâneo. In: Acta Semiótica e Linguística, v.15, p.201-215, São Paulo, 2010. ALMEIDA, M. L. L. et al. Linguística Cognitiva em foco: morfologia e semântica. Rio de Janeiro: Publt, 2010.

ARAGÃO, V.P. S. Investigações acerca do sufixo -ete. In: Anais do VII Congresso Internacional da Abralin. Curitiba: UFPR, 2011. p. 4326-4336.

BASILIO, M. Teoria Lexical. São Paulo: Ática, 1987.

BECHARA, E. Moderna Gramática Portuguesa. $37^{a}$ ed. Rio de Janeiro: Lucerna, 1999. 
BOOIJ, G. Construction Morphology. Oxford: Oxford University Press, 2010.

BOOIJ, G. Compounding and Derivation. Evidence for Construction Morphology. In: W. DRESSLER et al. (eds.). Morphology and its Demarcations. Amsterdam / Philadelphia: John Benjamins Publishing Company, pp. 109-131, 2005.

CÂMARA JUNIOR, J. M. História e estrutura da Lingua Portuguesa. Rio de Janeiro: Padrão, 1975.

CUNHA, C. F. Gramática da Lingua Portuguesa. Rio de Janeiro: FENAME, 1982.

FAUCONNIER, M. Mental spaces. Cambridge: Cambridge University Press, 1985.

FAUCONNIER, G. \& TURNER, M. The way we think. Conceptual blending and the mind hidden complexities. New York: Basic Books, 2002.

FERRARI, L. Introdução à Linguística Cognitiva. São Paulo: Contexto, 2011.

FERREIRA, A. B. de Holanda. O dicionário da Lingua Portuguesa (eletrônico). Curitiba: Ed. Positivo, 2008.

GOLDBERG, A. Constructions: a construction grammar approach to argument structure. Chicago; London: The University of Chicago Press, 1995.

GONÇALVES, C. A. V. Atuais tendências em formação de palavras no português brasileiro. Signum. Estudos de Linguagem, v. 15, p. 169-199, 2012.

GONÇALVES, C. A. V. Flexão e derivação em português. Rio de Janeiro: Ed. Faculdade de Letras da UFRJ, 2005.

GONÇALVES, C. A. V. \& ALMEIDA, M.L.L. Morfologia Construcional: principais ideias, aplicação ao português e extensões necessárias. Alfa, São Paulo, 58 (1): 165-193, 2014.

GONÇALVES, C. A. V. \& ALMEIDA, M.L.L. Das relações entre forma e conteúdo nas estruturas morfológicas do português. Diadorim, Rio de Janeiro, 5 (1); 31-50, 2008.

HOLANDA, A. B. de. Dicionário Eletrônico Aurélio da Lingua Portuguesa. Rio de Janeiro: Padrão, 2008. 
HOUAISS, A. Dicionário Eletrônico Houaiss da Lingua Portuguesa. Rio de Janeiro: Objetiva, 2009.

HUTCHINS, E. Anthropology in Cognitive Science. Topics in Cognitive Science, 2: 1550-1565, 2005.

KEHDI, V. Formação de palavras em português (Série Princípios). São Paulo: Ática, 1992.

LAKOFF, G. Women, fire and dangerous things: what categories reveal about the mind. Chicago: Chicago University Press, 1987.

LANGACKER, R. W. Foundations of cognitive grammar. v. I: theoretical prerequisites. Stanford: University Press, 1987.

LE ROBERT - Dictionnaire alphabétique et analogique de la langue française. Paris. France: Dictionnaires Le Robert, 2001.

LOURES, L. H. R. S. Análise dos recursos morfológicos com função expressiva em português e francês. Rio de Janeiro: UFRJ, Faculdade de Letras, 2000. Tese de Doutorado em Linguística.

LUFT, Celso Pedro. Moderna Gramática Brasileira. Porto Alegre: Ed. Globo, 1979.

ROCHA LIMA, Carlos Henrique da. Gramática normativa da lingua portuguesa. Rio de Janeiro: José Olympio, 1979.

$\mathrm{ROSCH}, \mathrm{E} . \mathrm{H}$ "On the internal structure of perceptual and semantic categories". In: Moore, T. (Ed.). Cognitive Development and the Acquisition of Language. New York: Academic Press, 1973. SAID ALI, M. Gramática histórica da Lingua Portuguesa: Edições Melhoramentos, 1931.

SANDMANN, A. J. Formação de palavras no Português Brasileiro Contemporâneo. Curitiba: Scientia e Labor, 1988.

VAZQUEZ CUESTA, P. Gramática da Língua Portuguesa. Lexis, 1982. 


\section{Abstract}

Chacretes, ronaldetes and others -etes: a morphological and semantics analysis of $X$-ete constructions in Brazilian Portuguese

The aim of this paper is to analyze the X-ete formations of Brazilian Portuguese based on the Constructional Morphology (BOOIJ 2005, 2010) and issues of Cognitive Linguistics, such as CIMs (Cognitive Idealized Models), frames and mental spaces. We intend to check (a) which aspects of these models apply to the semantic analysis of this suffix and (b) if there are two different ['EtfI] formatives - the designator of fans ('ronaldete', 'neymarzete', 'luanzete') and the creator of names that means "dancer" / "stage assistant" ('chacrete', 'angeliquete', 'panicat').

Keywords: Morphology; Cognitive Linguistics; Analogy. 